\section{MONOMER STILBENOID GLUCOSIDES FROM Vatica pauciflora AND Vatica lowii (DIPTEROCARPACEAE)}

Aisyah Salihah Kamarozamana*, Jalifah Latip ${ }^{b}$, Christian Paetzc, Yana M. Syahd

aCentre of Foundation Studies, Universiti Teknologi MARA, 42300 Bandar Puncak Alam, Selangor, Malaysia bFaculty of Science and Technology, Universiti Kebangsaan Malaysia, 43600 Bangi, Selangor, Malaysia cMax Planck Institute for Chemical Ecology, Hans-Knöll-Straße 8, D-07745 Jena, Germany dFaculty of Mathematics \& Natural Sciences, Bandung Institute of Technology (ITB), 40132 Bandung, Indonesia
Article history

Received

23 March 2015

Received in revised form

13 July 2015

Accepted

20 August 2015

*Corresponding author aisyahsalihah@yahoo.co.uk

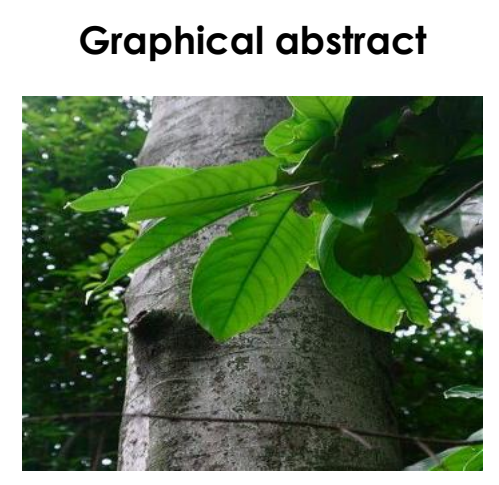

\begin{abstract}
Phytochemical studies on the woods of Vatica pauciflora and Vatica lowii have been conducted. The woods of $V$. pauciflora were extracted with methanol by using Soxhlet apparatus while the woods of $V$. lowii were extracted with acetone at room temperature. The methanolic extract of $V$. pauciflora was semi-purified by using vacuum liquid chromatography (VLC) and further purified by high performance liquid chromatography (HPLC) to obtain a pure compound (1). The same technique of semi-purification has been employed on $V$. lowii acetone extract which was further purified by radial chromatography to give a pure compound (2). Based on the UV, IR, NMR and mass spectral data, the isolated compounds were characterized as (-)-cis-resveratrol-10-C- $\beta$-D-glucopyranoside and (-)-piceid respectively.
\end{abstract}

Keywords: V. pauciflora, V. lowii, (-)-cis-resveratrol-10-C- $\beta$-D-glucopyranoside, (-)-piceid

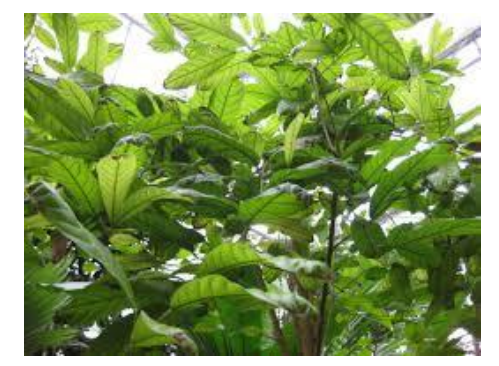

\begin{abstract}
Abstrak
Kajian fitokimia ke atas bahagian kayu Vatica pauciflora dan Vatica lowii telah dijalankan. Bahagian kayu $V$. pauciflora telah diekstrak dengan metanol menggunakan Soxhlet manakala bahagian kayu $V$. lowii diekstrak dengan aseton pada suhu bilik. Ekstrak metanol V. pauciflora telah dipisahkan separa dengan kromatografi cecair vakum (VLC) dan selanjutnya ditulenkan dengan kromatografi cecair prestasi tinggi (HPLC) bagi menghasilkan sebatian tulen (1). Teknik yang sama telah digunakan ke atas ekstrak aseton $\checkmark$. lowii yang seterusnya dipisahkan menggunakan kromatografi jejarian bagi menghasilkan sebatian tulen (2). Berdasarkan data spektrum UL, IM, RMN dan MS, sebatian yang diasingkan masing-masing dicirikan sebagai (-)-cis-resveratrol-10-C- $\beta$-D-glukopiranosida dan (-)-piseid.
\end{abstract}

Kata kunci: V. pauciflora, V. lowii, (-)-cis-resveratrol-10-C- $\beta$-D-glukopiranosida, (-)-piseid

(C) 2015 Penerbit UTM Press. All rights reserved 


\subsection{INTRODUCTION}

Dipterocarpaeceae family is not only known to contain abundant sources of oligostilbenoids but also an important source in timber production [1,2]. The family members of Dipterocarpaceae usually found in lowland area as well as on the hill. Based on the research by Cronquist, Borneo and Peninsula Malaysia are rich in these species with 16 genera and almost 600 species were recorded in these areas [3].

The Vatica genus belongs to the largest subfamily in Dipterocarpaceae which is Dipterocarpoideae. The species from this genus which is mainly found in Borneo and Malay Peninsula usually occur in the lowland area below 1000 feet, hill-forest between 2000 and 3000 feet and peat swamp forests $[4,5]$.

Most of Vatica species are relatively smaller compared to other genus in Dipterocarpaceae family such as Shorea, Hopea and Neobalanocarpus. As the wood is undurable, this genus has less commercial importance and is usually used in temporary constructions [5]. However, this genus can produce resin in small and large quantity depending on the species $[4,5]$.

$\checkmark$. pauciflora is one of the most species used as laru to prevent fermentation of toddy [5 - 7]. The trees are small medium-sized and produced yellowish dammar which can be found in the branches. The stipules are oblong while the leaves are usually elliptic and oval. The flowers are creamy white in colour with some redness at the bottom of the petals. The fruits are in various sizes with pale pinkish brown colour [4].

$V$. lowii is a species found on the hill with 2000 feet from the sea level. The trees reached 60 to 80 feet high and the size of the stem is 18 to 24 inches. The leaves are small and glossy green while the colours of the flowers are white. However, very little information is reported on the usage of $\mathrm{V}$. lowii [4].

The previous study by Ito and co-workers on the stem bark of $V$. pauciflora originated from Indonesia have successfully isolated a non-oligomer compound and 26 stilbene oligomers which eight of them are new compounds namely pauciflorols A-E; isovaticanols $B$ and $C$ and pauciflorosides A-C. The other 16 known stilbene oligomers reported are from monomer to tetramer stilbenoids [1].

Subsequent work done by the same researchers [8] has successfully isolated three new oligomer stilbenoids which one of them is a heptamer stilbenoid. Meanwhile, V. lowii has not been studied by any researcher yet.

Many studies done on the species from this family have revealed significant bioactivities results that may contribute to the development of drugs and natural antioxidant [9]. Biological studies done on some of these isolated chemical constituents of $V$. pauciflora revealed significant cytotoxic activities against murine leukemia P-388 [10, 11], colon cancer SW480, leukemia HL60 cell lines [9] as well as chemoprevention effect on liver Chang cells [12].

In searching for the potential natural and pharmaceutical products for medicinal purposes, the isolation on Malaysia's V. pauciflora and V. lowii have been done to isolate the potential oligostilbenoids from these species. Apart from that, this study is also done to compare the chemical constituents in the same species but from different origin.

\subsection{EXPERIMENTAL}

\subsection{Analysis}

The structures of compound (1) and (2) were elucidated by means of infrared (IR), ultravioletvisible (UV-VIS), mass (MS) and one and two dimensioned nuclear magnetic resonance spectroscopy (1D and 2D NMR), optical rotation analysis and direct comparison with literature data. Chemical shift, $\delta$, ppm recorded in $\mathrm{CD}_{3} \mathrm{OD}$ and $\mathrm{CD}_{3} \mathrm{COCD}_{3}$.

\subsection{Plant Materials}

V. pauciflora was collected from Gunung Panti, Pontian, Johor, Malaysia in August 2006 while V. lowii was collected from Lata Belatan, Jertih, Terengganu, Malaysia in March 2007. The voucher specimens (WYP 15 and WYA 116 respectively) were deposited at the Herbarium of Universiti Kebangsaan Malaysia.

\subsection{Extraction and Isolation}

The woods of $V$. pauciflora were dried and ground to form powder. The powder of the woods (400 g) was then extracted with $n$-hexane, ethyl acetate and methanol by using Soxhlet apparatus. The extractions were done for $8 \mathrm{hr}$ and were repeated for three times. The extracts were dried by using rotary evaporator to give crudes extracts VHB (3.00 g), VEB $(9.48 \mathrm{~g})$ and VMB (16.73 g). The crude methanol extract was then fractionated by Vacuum Liquid Chromatography (VLC) with a mixture of $n$-hexaneethyl acetate in increasing polarity to give 14 fractions (VMBO1-14). Fraction VMB15 (798.6 mg), which was a polar fraction was further purified by high performance liquid chromatography (HPLC) with gradient elvent of acetonitrile, trifluoroacetic acid (TFA) and methanol to give nine fractions (VMB151-159) which one of them was a pure compound (1) $(0.3 \mathrm{mg})$. The pure compound was obtained as brownish viscous oil. The quasi-molecular ion $[\mathrm{M}+\mathrm{Na}]^{+}$peak was recorded at $\mathrm{m} / \mathrm{z} 413$ (100\%). The absorption of UV spectrum in methanol was recorded at $\lambda_{\max } 212,284 \mathrm{~nm}$.

The woods of $V$. lowii were dried and ground to form powder. The powder of the woods $(2.3 \mathrm{~kg})$ was then extracted with acetone at room temperature followed by ethanol for 24 hours and repeated three times. The extracts were dried by using rotary evaporator to give crudes extracts VLBA $(60.45 \mathrm{~g})$ and VLBT $(69.88 \mathrm{~g})$. The crude acetone extract was subjected to VLC with a mixture of $n$-hexane-ethyl 
acetate in increasing polarity to give six fractions (VLBA 1-6). Fraction VLBA6 (1.2 g) was further purified by radial chromatography $(\mathrm{RC})$ using gradient elvent of chloroform and methanol (8:2) to give six fractions (VLBA61-66) which one of them was pure (2) (11.1 $\mathrm{mg}$ ). The pure compound was obtained as brownish needle. The ESI-MS spectrum recorded the quasimolecular ion $[\mathrm{M}-\mathrm{H}]^{+}$at $\mathrm{m} / \mathrm{z} 389$. The absorption of UV spectrum in methanol was recorded at $\lambda$ max 225,298 $\mathrm{nm}$. When the UV spectrum was recorded in the presence of $\mathrm{NaOH}$, bathochromic shift was observed in which $\lambda_{\max } 225$ shifted to $237 \mathrm{~nm}$ and $\lambda_{\max } 298$ to $314 \mathrm{~nm}$

\subsection{RESULTS AND DISCUSSION}

Compound (1) was obtained from the wood extract of $V$. pauciflora as brownish viscous oil. The quasimolecular ion $[\mathrm{M}+\mathrm{Na}]^{+}$peak indicated a molecular formula of $\mathrm{C}_{20} \mathrm{H}_{22} \mathrm{O}_{8}$. The UV spectrum showed a characteristic of an aromatic and phenol. This absorption is a typical signal of oligostilbenoid with cis-stilbene skeleton [13, 14]. The presence of aromatic and phenol are supported by the IR absorption at $3334(\mathrm{O}-\mathrm{H}) ; 1611$ and $1453 \mathrm{~cm}^{-1}(\mathrm{C}=\mathrm{C}$ Ar). Absorption at 1200 and $1002 \mathrm{~cm}^{-1}$ suggested the presence of ether (C-O-C).

The 'H NMR spectrum of (1) showed the presence of four aromatic protons at $\delta_{\mathrm{H}} 7.05$ - 6.13. Two doublets $(\mathrm{J}=8.8 \mathrm{~Hz})$ at $\delta \mathrm{H} 7.05$ and 6.57 indicated the presence of 1,4-disubstituted aromatic ring. Two meta-coupled aromatic signals $\left(\mathrm{J}=2.5 \mathrm{~Hz}\right.$ ) at $\delta_{\mathrm{H}} 6.21$ and 6.13 showed the presence of another tetrasubstituted aromatic ring. Two mutually coupled doublets $(\mathrm{J}=12.1 \mathrm{~Hz})$ at $\delta_{\mathrm{H}} 6.13$ and 6.15 indicated the presence of olefinic protons which are cis to each other. Other signals at $\delta_{H} 4.68-3.17$ are typical for glycoside protons. A broad singlet at $\delta_{H} 4.68$ exhibited the presence of anomeric proton while another broad singlet at $\delta_{\mathrm{H}} 3.73$ and doublet at $\delta_{\mathrm{H}}$ 3.71 assigned to methylene protons of glucoside molecule.

Since only a minute amount of this compound obtained, the ${ }^{13} \mathrm{C}$ - APT NMR spectrum was not recorded. However, the signals shown in ${ }^{1} H$ NMR and COSY spectra of (1) are consistent with the literature [15] and is characterized as (-)-cis-resveratrol-10-C- $\beta$ D-glucopyranoside (1).

Compound (2) was obtained from the wood extract of $V$. lowii as brownish needle. The ESI-MS spectrum recorded the quasi-molecular ion $[\mathrm{M}-\mathrm{H}]^{+}$ corresponding to a molecular formula of $\mathrm{C}_{20} \mathrm{H}_{22} \mathrm{O}_{8}$. The UV spectrum showed the presence of aromatic and phenolic system. When the UV spectrum was recorded in the presence of $\mathrm{NaOH}$, bathochromic shifts were observed with the value $\lambda_{\max } 237$ and 314 $\mathrm{nm}$ which indicated the presence of trans-stilbene skeleton in the molecule [13, 14]. The IR spectrum supported the presence of phenol ring at $3379(\mathrm{O}-\mathrm{H})$ and $1655 \mathrm{~cm}^{-1}(\mathrm{C}=\mathrm{C} \mathrm{Ar})$. The absorption at $1032 \mathrm{~cm}^{-1}$ suggested that this compound contain functional group of ether (C-O-C).

The ${ }^{1 H}$ NMR spectrum of (2) displayed five aromatic signals at the range of $\delta_{H} 7.42-6.45$. Two doublets $(\mathrm{J}=8.4 \mathrm{~Hz})$ at $\delta \mathrm{H} 7.42$ and 6.83 indicated the presence of 1,4-disubstituted aromatic ring. Three triplets $(\mathrm{J}=1.8 \mathrm{~Hz})$ at $\delta \mathrm{H} 6.80,6.66$ and 6.45 indicated the presence of 1,3,5-trisubstituted aromatic ring. Two doublets $(\mathrm{J}=16.4 \mathrm{~Hz})$ at $\delta_{\mathrm{H}} 7.10$ and 6.92 indicated the presence of two olefinic protons which are trans to each other. The signals at $\delta_{\mathrm{H}} 4.93$ - 3.45 were typical signals for glycoside protons where a doublet $(\mathrm{J}=7.7 \mathrm{~Hz})$ at $\delta \mathrm{H} 4.93$ indicated the anomeric proton in $\beta$-configuration. Other prominent signals are a doublet $(J=11.7 \mathrm{~Hz})$ at $\delta_{H} 3.92$ and a double of doublets $(\mathrm{J}=11.7,1.8 \mathrm{~Hz})$ at $\delta_{\mathrm{H}} 3.72$ were typical of methylene protons of a glucopyranoside.

The ${ }^{13} \mathrm{C}$ - APT NMR spectrum of (2) exhibited eighteen signals which represent twenty carbons. The presence of oxyaryl carbons were shown by the signals at $\delta c 158.3,159.4$ and 160.3. Additionally, two quaternary carbons observed at $\delta c 129.9$ and 140.8 and seven aromatic carbons at $\delta c 103.8,106.4,108.2$, $116.4,116.4,128.8$ dan 128.8. The remaining signals represent two olefinic carbons at $\delta c 126.4$ and 129.6 and six glucoside carbons at $\delta c 62.7,71.4,74.7,77.9$, 78.1, 102.0. The data comparison of the ${ }^{1} \mathrm{H}$ and ${ }^{13} \mathrm{C}-$ APT NMR were consistent with the literature [16] and is characterized as (-)-piceid (2).

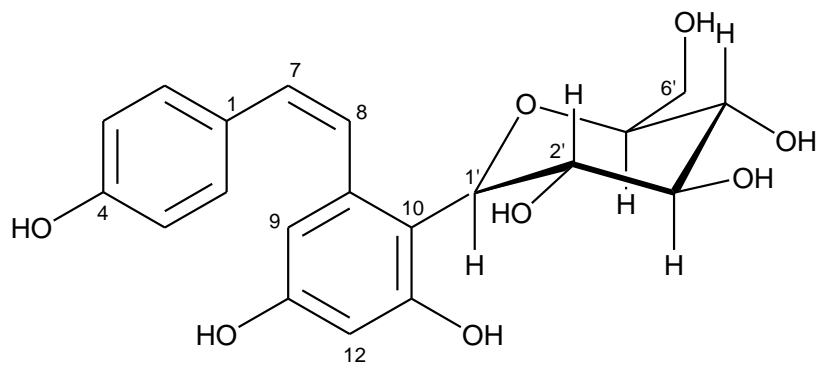

(1)<smiles>Oc1ccc(C=Cc2cc(O)cc(O[C]3O[C@H]4O[C@@H]3[C@@H](O)[C@@H]4O)c2)cc1</smiles>

(2) 
The isolation of Malaysia's $V$. pauciflora found that only three oligostilbenoid compounds are similar to the Indonesian species namely $(-)-\varepsilon$-viniferin, (+)vaticanol $G$ and (-)-vaticanol B [1, 12]. However, (-)cis-resveratrol-10-C- $\beta$-D-glucopyranoside (1) is only present in Malaysian species. The difference on the presence of these compounds is due to the locality of the species which might be influenced by the soil as well as the environment of the species.

\subsection{CONCLUSION}

In conclusion, the woods of $V$. pauciflora and $V$. lowii were found to contain monomer stilbenoid glucosides namely (-)-cis-resveratrol-10-C- $\beta-D-$ glucopyranoside (1) and (-)-piceid (2) respectively. Both monomer stilbenoid glucosides are reported for the first time for each species respectively. The isolation of Malaysia's $V$. pauciflora exhibited slightly different compounds compared to the Indonesian species. (-)-cis-resveratrol-10-C- $\beta$-D-glucopyranoside (1) was only found in Malaysian species while other oligostilbenoids namely (-)-E-viniferin, (+)-vaticanol $G$ as well as (-)-vaticanol $B$ are among the compounds that are present in both species [1, 12].

\section{Acknowledgement}

The Ministry of Science, Technology and Innovation (MOSTI), Malaysia and Centre of Foundation Studies, UiTM Puncak Alam, are acknowledged for the financial support (MOSTI ESciencefund 02-01-02SF0197).

\section{References}

[1] Ito, T., Tanaka, T., linuma, M., lliya, I., Nakaya, K. I., Ali, Z., Takahashi, Y., Sawa, R., Shirataki, Y., Murata, J., Darnaedi, D. 2003. New Resveratrol Oligomers in the Stem Bark of Vatica pauciflora. Tetrahedron. 59 (28): 5347-5363.
[2] Newman, M. F., Burges, P. F., Whitemore, T. C. 1999. Pedoman Identifikasi Pohon Dipterocarpaceae Pulau Kalimantan. Bogor: Prosea.

[3] Cronquist, A. 1981. An Integrated System of Classification of Flowering Plants. New York: Columbia University Press.

[4] Symington, C. F. 1974. Foresters' Manual of Dipterocarps. Kuala Lumpur: Universiti Malaya.

[5] Foxworthy, F. W. 1932. Dipterocarpaceae of the Malay Peninsula. Malayan Forest Records No. 10. Singapore.

[6] Burkill, I. H. 1966. A Dictionary of the Economic Products of the Malay Peninsula. Jil. 2. Kuala Lumpur: Art Printing Works.

[7] Desch, H. E. 1941. Dipterocarp Timbers of The Malay Peninsula Malayan Forest Records No. 14. Kuala Lumpur.

[8] Ito, T., Tanaka, T., linuma, M., Nakaya, K., Takahashi, Y., Sawa, R., Murata, J., Darnaedi, D. 2004. Three New Resveratrol Oligomers from the Stem Bark of Vatica pauciflora. Journal of Natural Products. 67(6): 932-937.

[9] Ito, T., Akao, Y., Yi, H., Ohguchi, K., Matsumoto, K., Tanaka, T., linuma, M. \& Nozawa, Y. 2003. Antitumor Effect Of Resveratrol Oligomers Against Human Cancer Cell Lines and the Molecular Mechanism of Apoptosis Induced by Vaticanol C. Carcinogenesis. 24(9): 1489-1497.

[10] Muhtadi, hakim, E. H., Lia, D. J., Syah, Y. M., Sjamsul, A., Latip, J., and Emilio, L. G. 2006. Cytotoxic Resveratrol Oligomers from the Tree Bark of Dipterocarpus hasseltii. Fitoterapia. 77: 550-555.

[11] Haryoto, S., Lia, D.J., Syah, Y. M., Achmad, S. A., Hakim, E. H., Latip, J., and Said, I. M. 2008. Oligostilbenoids from Shorea gibbosa and Their Cytotoxic Properties Against P388 Cells. Journal of Natural Medicines. 62: 195-198.

[12] Kamarozaman, A. S., Latip, J., Syah, Y. M., Rajab, N. F., Jaloh, A. 2013. Oligostilbenoids from Vatica pauciflora and the Oxidative Effect on Chang Cells. In J. Phys: Conf. Ser. 2013 International Conference on Science \& Engineering in Mathematics, Chemistry and Physics (ScieTech 2013), Jakarta. 24-25 January 2013. 423

[13] Mattifi, F. and Reniero, F. 1996. Relationship between UV Spectra and Molecular Structure of Resveratrol Oligomers. Polyphenols Communications. 96(1): P53-P54.

[14] Syah, Y. M, Aminah, N. S., Hakim, E. H., Aimi, N., Kitajima, M., Takayama, H., and Achmad, S.A. 2003. Two oligostilbenes, cis- and trans-diptoindonesin B, from Dryobalanops oblongifolia. Phytochemistry. 63: 913-917.

[15] Baderschneider, B. and Winterhalter, P. 2000. Isolation and Characterization of Novel Stilbene Derivatives from Riesling Wine. Journal of Agricultural and Food Chemistry. 48: 2681-2686

[16] Orsini, F., Pelizzoni, F., Verotta, L. and Aburjai, T. 1997. Isolation, Synthesis and Antiplatelet Aggregation Activity of Resveratrol 3-O- $\square$-D-glucopyranoside and Related Compounds. Journal of Natural Products. 60: 1082-1087. 